\title{
HARD TIMES
}

TOM CLARK writes daily editorials on economics, politics and society for the Guardian. He runs the newspaper's opinion polling, and hosts a weekly podcast. He previously advised the last Labour government, after five years at the Institute for Fiscal Studies where he published peer-reviewed papers on poverty, inequality and social security. He has co-authored a book on ethnic diversity, The Age of Obama (2010).

Anthony Heath is professor of sociology, University of Manchester, and emeritus professor at the University of Oxford. In 2013 he was awarded a CBE in the Queen's Birthday Honours List. His most recent book is The Political Integration of Ethnic Minorities in Britain (2013). 


\title{
HARD TIMES INEQUALITY, RECESSION, AFTERMATH
}

\author{
TOM CLARK \\ WITH ANTHONY HEATH
}

YALE UNIVERSITY PRESS

NEW HAVEN AND LONDON 


\section{Copyright (C) 2014 Tom Clark}

First published in paperback in 2015

The right of Tom Clark to be identified as the author of this work has been asserted by him in accordance with the Copyright, Designs and Patents Act 1988.

All rights reserved. This book may not be reproduced in whole or in part, in any form (beyond that copying permitted by Sections 107 and 108 of the U.S. Copyright Law and except by reviewers for the public press) without written permission from the publishers.

For information about this and other Yale University Press publications, please contact:

U.S. Office: sales.press@yale.edu_www.yalebooks.com

Europe Office: sales@yaleup.co.uk www.yalebooks.co.uk

Set in Sabon by IDSUK (DataConnection) Ltd

Printed in Great Britain by Hobbs the Printer Ltd, Totton, Hampshire

Library of Congress Cataloging-in-Publication Data

Clark, Tom, 1976-

Hard times : the divisive toll of the economic slump / Tom Clark, with

Anthony Heath.

pages $\mathrm{cm}$

Includes bibliographical references and index.

ISBN 978-0-300-20377-6 (alk. paper)

1. United States-Economic conditions-2009- 2. United States-Social

conditions. 3. Great Britain-Economic conditions-1997- 4. Great

Britain-Social conditions. 5. Recessions-Social aspects. 6. Global Financial

Crisis, 2008-2009-Social aspects. I. Heath, A. F. (Anthony Francis) II. Title.

HC106.84.C53 2014

$330.973-\mathrm{dc} 23$

2014002243

A catalogue record for this book is available from the British Library.

ISBN 978-0-300-21274-7 (pbk)

10987654321

iv 
For my mother T.C. 
